NBER WORKING PAPER SERIES

\title{
OPENNESS AND INDUSTRIAL RESPONSES IN A WAL-MART WORLD: A CASE STUDY OF MEXICAN SOAPS, DETERGENTS AND SURFACTANT PRODUCERS
}

\author{
Beata Smarzynska Javorcik \\ Wolfgang Keller \\ James Tybout \\ Working Paper 12457 \\ http://www.nber.org/papers/w12457
}

\author{
NATIONAL BUREAU OF ECONOMIC RESEARCH \\ 1050 Massachusetts Avenue \\ Cambridge, MA 02138 \\ August 2006
}

We gratefully acknowledge funding from the Office of the World Bank's Chief Economist for Latin America and the World Bank's Research Support Budget. We also wish to thank Mexican and multinational companies, the Mexican National Oils, Fats, Soaps and Detergents Industry Association (CANAJAD) and the Mexican National Chamber of Manufacturing (CANACINTRA) for making this study possible by being generous with their time. Thanks are also due to Isidro Soloaga for his invaluable help with conducting firm interviews in Mexico and Geoff Revell for superb research assistance. The findings, interpretations, and conclusions expressed in this paper are entirely those of the authors. They do not necessarily represent the view of the World Bank, its Executive Directors, or the countries they represent. The views expressed herein are those of the author(s) and do not necessarily reflect the views of the National Bureau of Economic Research.

C2006 by Beata Smarzynska Javorcik, Wolfgang Keller and James Tybout. All rights reserved. Short sections of text, not to exceed two paragraphs, may be quoted without explicit permission provided that full credit, including (C) notice, is given to the source. 
Openness and Industrial Response in a Wal-Mart World: A Case Study of Mexican Soaps, Detergents and Surfactant Producers

Beata Smarzynska Javorcik, Wolfgang Keller and James Tybout

NBER Working Paper No. 12457

August 2006

JEL No. F1, F23, L65, L81

\begin{abstract}
$\underline{\text { ABSTRACT }}$
This paper uses a case study approach to explore the effects of NAFTA and GATT membership on innovation and trade in the Mexican soaps, detergents and surfactants (SDS) industry. Several basic findings emerge. First, the most fundamental effect of NAFTA and the GATT on the SDS industry was to help induce Wal-Mart to enter Mexico. Once there, Walmex fundamentally changed the retail sector, forcing SDS firms to cut their profit margins and/or innovate. Those unable to respond to this new environment tended to lose market share and, in some cases, disappear altogether. Second, partly in response to Walmex, many Mexican producers logged impressive efficiency gains during the previous decade. These gains came both from labor-shedding and from innovation, which in turn was fueled by innovative input suppliers and by multinationals bringing new products and processes from their headquarters to Mexico. Finally, although Mexican detergent exports captured an increasing share of the U.S. detergent market over the past decade, Mexican sales in the U.S. were inhibited by a combination of excessive shipping delays at the border and artificially high input prices (due to Mexican protection of domestic caustic soda suppliers). They were also held back by the major re-tooling costs that Mexican producers would have had to incur in order to establish brand recognition among non-Latin consumers, and in order to comply with zero phosphate laws in many regions of the United States.
\end{abstract}

Beata Smarzynska Javorcik

World Bank

MSN MC3-303

1818 H St., NW

Washington, DC 20433

bjavorcik@worldbank.org

Wolfgang Keller

Department of Economics

University of Colorado at Boulder

Boulder, CO 80309-0256

and NBER

wolfgang.keller@colorado.edu
James R. Tybout

Department of Economics

Penn State University

517 Kern Graduate Building

University Park, PA 16802

and NBER

jtybout@psu.edu 


\section{Introduction}

Between the mid 1980s and the mid 1990s, Mexico substantially reduced its trade barriers and liberalized its foreign investment code. The initial wave of commercial policy reforms was locked into place when Mexico joined the General Agreement on Tariffs and Trade (GATT) in 1985. Further liberalization vis a vis the United States and Canada was codified in the North American Free Trade Agreement (NAFTA) signed in 1992 and implemented on January 1, 1994. Thus by the early 1990s, Mexico had committed itself to integration with the global economy in general, and it had opened its markets especially relative to the United States.

This paper uses a case study approach to explore the effects of these policies on innovation and trade in the Mexican soaps, detergents and surfactants (SDS) industry. Rather than simply examine the correlation of trade barriers with trade flows and FDI barriers with FDI flows, the objective is to develop a more nuanced understanding of the channels through which Mexico's opening has affected industrial sector performance, and where responses are lacking, to understand why.

Several basic messages emerge. First, according to the SDS firms that were interviewed, the most profound effect of NAFTA and the GATT on the SDS industry was neither a reduction in trade costs nor an inflow of rival multinational subsidiaries. Rather, it was a fundamental change in the relationship between these firms and their retailers. Reductions in trade barriers made Mexico a more attractive market for WalMart, which found that it could profitably bring consumer goods into the country from the United States. Once Walmex (Wal-Mart of Mexico) was established, it changed the way that SDS producers and other suppliers of consumer goods interacted with retailers. 
By exercising its bargaining power, it squeezed profit margins among the major brands, offering them higher volumes in return. It also engaged the most efficient small-scale local producers as suppliers of store brands, thereby creating for itself a residual source of SDS products that could be used in bargaining with the major (multinational) branded suppliers. Those local firms that were not efficient enough to meet Walmex's terms lost market share, and many failed. At the same time, the limited set of producers that survived grew, and with prodding from Walmex they became more efficient and innovative, adopting innovations first introduced into the market by their multinational competitors. A similar transformation took place among retailers themselves in reaction to the new business practices that Walmex brought to the country.

The second basic message is that Mexican SDS exporters have managed to gain market share in the U.S. since the mid-1990s, but their ability to build on this trend is constrained by a combination of factors. The export growth that they have achieved thus far has targeted the expanding Latino community in the United States, where their brands are already known. If these producers are to penetrate the non-Latino U.S. market, substantial marketing investments will be necessary. They will also need to retool for the production of phosphate-free concentrates, which are required by law in much of the U.S. SDS exports are further impeded by substantial delays at the U.S./Mexican border, which have increased shipping costs by 9 to 15 percent. And the competitiveness of Mexican SDS products abroad is compromised by the fact that one of their key inputs - caustic soda - is protected in Mexico by an anti-dumping ruling, driving up marginal production costs. 
It is possible — but far from certain — that the cost savings associated with the removal of border frictions and protection for caustic soda producers would be sufficient to induce producers to invest in marketing and in re-tooling. If this were to happen, a discrete surge in Mexican detergent exports might occur.

The final basic message is that the SDS sector rapidly improved its value-added per worker after the mid 1990s, and that this reflected a combination of labor-shedding and innovative activity. The latter was facilitated by the presence of multinationals in several respects. Most directly, SDS subsidiaries drew on the research efforts of their headquarters abroad. But the Mexican-owned firms also benefited from multinationals, both through imitation and through their interactions with foreign-owned suppliers, who regularly approached them with new inputs and suggestions for new products and processes. Additionally, large retailers, such as Walmex, provided a stimulus for small and medium-sized suppliers to adopt innovations and improve production efficiency.

\section{Wal-Mart's entry: a revolution in retailing}

The ascendance of Walmex

As the Mexican economy began to open in the mid 1980s, its retail sector began a process of profound transformation. Drawing on interviews with industry managers and supporting data from INEGI, Chavez (2002) provides an excellent synopsis and interpretation of the changes that occurred. This subsection summarizes his main findings, devoting particular attention to the changes that were important for the performance of the SDS industry. 
Mexican producers of consumer goods were heavily protected until the mid 1980s. Thus retailers based in the United States — whose strength was in dealing with their home-market suppliers — stayed out. But as tariffs fell over the following halfdecade, Mexican retailers began to offer more consumer goods imported from the United States. And when NAFTA locked in place commercial policy reforms while extending national treatment to foreign investors, the Mexican market became attractive to large United States-based retail chains. ${ }^{1}$ This attraction was heightened by Mexico's large population, its growing middle class, and its increasing urbanization.

Participation by foreign retailers in the Mexican market began when executives at several of the major Mexican retailers approached their counterparts in Texas and California concerning possible collaboration. And for their part, major retail chains in the United States took increasing interest in Mexico as the NAFTA negotiations progressed. ${ }^{2}$ These events triggered a wave of joint ventures between Mexican and foreign chains. In 1991 the largest Mexican firm involved in retailing, Aurrera (part of the Mexican commercial group CIFRA), formed a joint venture with Wal-Mart. Then, in 1992, Comercial Mexicana entered into a joint venture with Price-Cosco. Finally, in 1994 the Mexican supermarket chain Gigante entered into joint ventures with the French retailer Carrefour and with Office Depot. Only one important Mexican supermarket chain, Soriana, remained independent.

\footnotetext{
${ }^{1}$ Tegel (2003) also concludes that Mexico's unilateral liberalization and signing of the GATT in 1987 were key to the entrance of foreign retailers. Appendix 1 provides a more detailed discussion of the relevant GATT- and NAFTA-induced policy reforms.

${ }^{2}$ Chavez (2000) observes that "members of the chambers and associations of retailers were invited by their governments to take part in the negotiating commissions representing their sectors and members ... (fn 1 , p. 505).
} 
After familiarizing themselves with Mexico, and having brought their own strengths with them, some foreign retailing firms felt that they no longer needed local collaborators. Most importantly, Wal-Mart bought controlling interest in Aurerra in 1997 and became Wal-Mart de México (Walmex). For its part, the French retailer Carrefour left its partnership with Gigante, but remained in the Mexican market. ${ }^{3}$

With the influx of foreign retailers, a handful of major chains came to dominate the market, and many of the smaller retailers were forced to shut down. By 2001, "only 4 chains dominated the market: Wal-Mart de México with almost half (45.6 percent), Comerical Mexicana with a little over a fifth (20.6 percent), Gigante (15.5 percent) and Soriana (14 percent)" (Chavez, 2002, p. 507). By 2002, Walmex's total sales had grown to $\$ 10.1$ billion (Tegel, 2003), and by 2004 to $\$ 12.5$ billion (Wal-Mart, 2005).

\section{Changes in Business Practices}

The growing dominance of Wal-Mex helped to induce two fundamental changes in the Mexican retail sector. First, the sector modernized its warehousing, distribution, and inventory management. Second, it changed the way it interacted with its suppliers. The former changes partly reflected the growing availability of information technology. But they also reflected the innovations that Walmex imported from the United States. Walmex not only introduced the system of channeling deliveries from suppliers through centralized warehouses, it also requires delivery trucks to have appointments and drivers

\footnotetext{
3 "Many Mexican food retail analysts speculate that Carrefour used its relationship with Gigante to get to know the domestic market, and then shifted its strategy to operate solo ..." (Chavez, 2002, p. 512).
} 
to carry standard identification cards. ${ }^{4}$ Those that miss appointments are subject to fines. Shipments must be on standardized palettes (rentable from Walmex), they must be shrink-wrapped with corner protectors, and they are subject to third-party quality audits. ${ }^{5}$ Many of these innovations have diffused to the other major retail chains.

Walmex's hard-nosed style of negotiation with its suppliers may have been at least as important. Famously, Wal-Mart keeps negotiations with its suppliers as stark as possible — both in terms of the bargaining environment and in terms of the number of negotiable contract features. And because it controls such a large share of the retail market, this often amounts to a take-or-leave-it offer. In the United States, the company is exceptionally private about its business practices and its suppliers are very reluctant to discuss details (Fishman, 2003). ${ }^{6}$ However, former suppliers are more willing to talk. They agree that Wal-Mart's uniquely large market share gives it extraordinary bargaining power, and allows it drive its suppliers' profit margins very low. For standardized products, it demands annual price reductions, so those firms that are unable to frequently introduce new goods — and thus avoid establishing a benchmark price — are squeezed relatively more (Fishman, 2003). Those suppliers that balk at Wal-Mart's demands are simply discontinued, and new suppliers are brought in.

Evidence on retail prices in the United States confirms that the "Wal-Mart squeeze" (Fishman, 2003) is real, and quantitatively important. Using region-specific

\footnotetext{
${ }^{4}$ Tegel (2003) states that Walmex is "the only Mexican retail chain that has its own centralized distribution system. Suppliers thus can deliver their goods just once to any of 11 Walmex depots scattered across the country, rather than to each individual store." Interviews for this study revealed that since the time of Tegel's writing, other major retailers have gone to centralized warehouses.

${ }^{5}$ These features of Walmex's delivery system were mentioned by several SDS firms interviewed for the present study.

${ }^{6}$ One company that helps businesses work with retailers commented "'If Wal-Mart takes something the wrong way, it's like Saddam Hussein. You just don't want to $\mathrm{p}$ them off." (Fishman, 2003)
} 
prices of several specific consumer goods, Basker (2005) develops an econometric model of price adjustments when a new Wal-Mart enters a region. Controlling for serial correlation, seasonal effects, city fixed effects, and endogenous opening dates, he finds that the long run effect of a new Wal-Mart is to drive down retail prices by from 1 percent to 13 percent, depending upon the product. For present purposes it is worth noting that the effect on detergent prices is relatively large-about 9 percent. This may be due to the fact that this product is fairly standardized, and thus subject to annual demands for price concessions.

Basker's (2005) findings are consistent with anecdotal evidence, which suggests that "when Wal-Mart enters a market, its everyday low prices are anywhere from 5 percent to 25 percent lower for identical goods." (Business Planning Solutions, 2005). They are also consistent with more aggregated econometric analyses that link regionspecific consumer commodity-price indices to the share of Wal-Mart stores in local retailing (Business Planning Solutions, 2005).

\section{Responses of Mexican SDS Producers to Wal-Mart's Entry}

The above characterization of Wal-Mart's effect on pricing in the United States is completely consistent with the observations that Mexican SDS manufacturers offered regarding Walmex during our interviews. Indeed, the appearance of Walmex was typically cited as the most important structural change to market since 1990.

One fundamental effect of Walmex, cited by both the major brands and the smaller suppliers, was to change the relative bargaining position of small and large firms. More precisely, Walmex uses roughly 25 domestically-owned small and medium-sized 
producers to supply store-brand (marca blanca) detergents and cleaners, each producing a differentiated product. These firms are efficient enough to survive at the prices Walmex offers them, and while most had previously been fringe players, they now collectively provide Walmex with a credible bargaining tool when it sits down with representatives of the major brands.

In addition to reducing suppliers' bargaining power, small suppliers and major brand suppliers agreed that it has increased industry-wide efficiency. One way, of course, has been to drive high-cost suppliers out of business. But those able to survive on Walmex's terms have been able to reach a much larger market and thereby exploit scale economies. Even the major brand suppliers agreed that Walmex's distribution system had made retailing more efficient.

The firms visited for this study were by definition survivors, and most were currently dealing with Walmex. So our sample under-represents the opinions of firms that have been made worse off by its market dominance. But those small and medium producers who addressed the issue indicated that they preferred the current business environment to the earlier epoch in which competition was more muted, relations with buyers were more social, and side payments for contracts were not unusual. Several mentioned how clubby the retailers had been before Walmex arrived, and noted that Walmex quickly withdrew from the National Association of Retailer and Department Stores after discovering that the Association's culture did not suit Wal-Mart's business model.

In light of these observations, it is interesting to examine the value-added prices of SDS producers, which net out the effects of materials price changes. Figure 1 shows 
SDS value-added prices along with prices for other products in the chemical industry. ${ }^{7}$

The latter series is included as a benchmark because these are products that use related technologies, but most are not consumer goods, and thus are not subject to the Walmex effect. To provide an additional benchmark, an aggregate value-added price index for the manufacturing sector is also included. While one can easily read too much into this graph, it does confirm that inflation rates came down relatively rapidly in the SDS and cosmetics sector as the structural transformation of the retail sector took shape in the late 1990s and early 2000s. (The spike in 1995 reflects the Tequila Crisis and the associated devaluation—refer to the appendix for details.)

Figure 1: Annual inflation rates and value-added prices

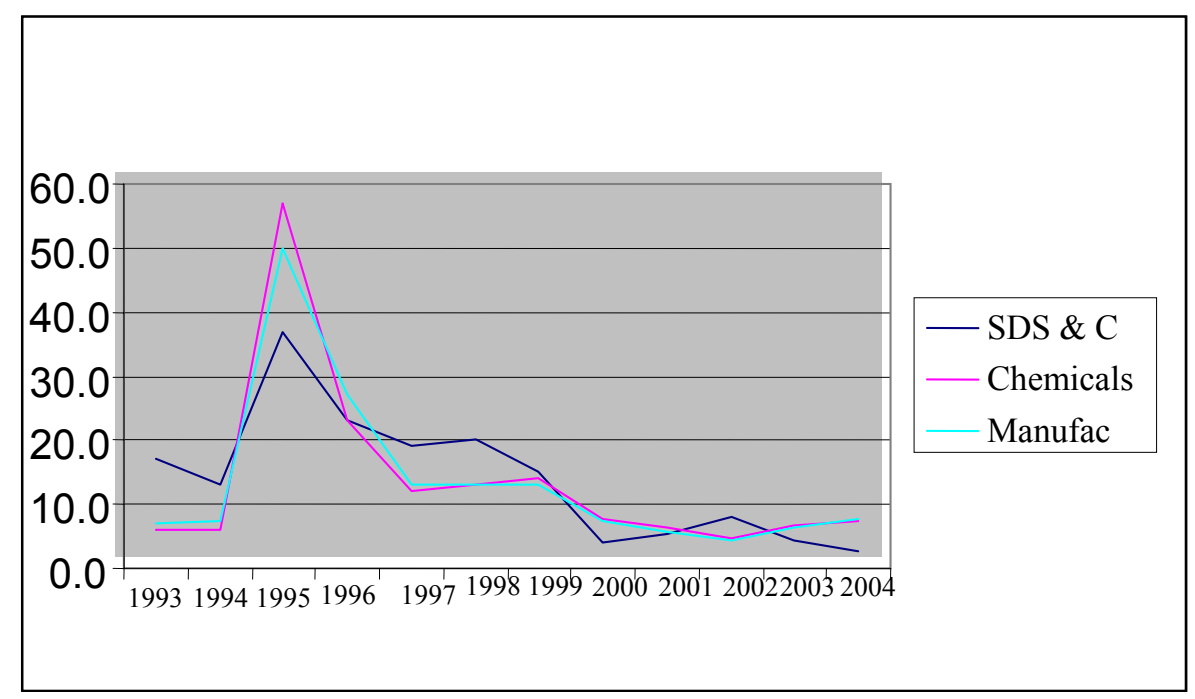

Source: INEGI (2005)

Some interviewees mentioned that one of the difficulties they faced was their inability to pass increases in material prices on to consumers, and they traced this

\footnotetext{
${ }^{7}$ Note that cosmetics are included with SDS products in the available series- since these are also consumer goods sold by Walmex, this should not change the basic message.
} 
problem partly to their lack of bargaining power vis a vis Walmex. While it is true that the rate of inflation in value-added prices has been below industry norms in all years except one since 1999, this has not translated into lower gross profit margins for SDS and cosmetics producers overall. As figure 2 demonstrates, the opposite has been the case:

\section{Figure 2}

\section{Gross Margins: All Chemicals versus SDS and Cosmetics}

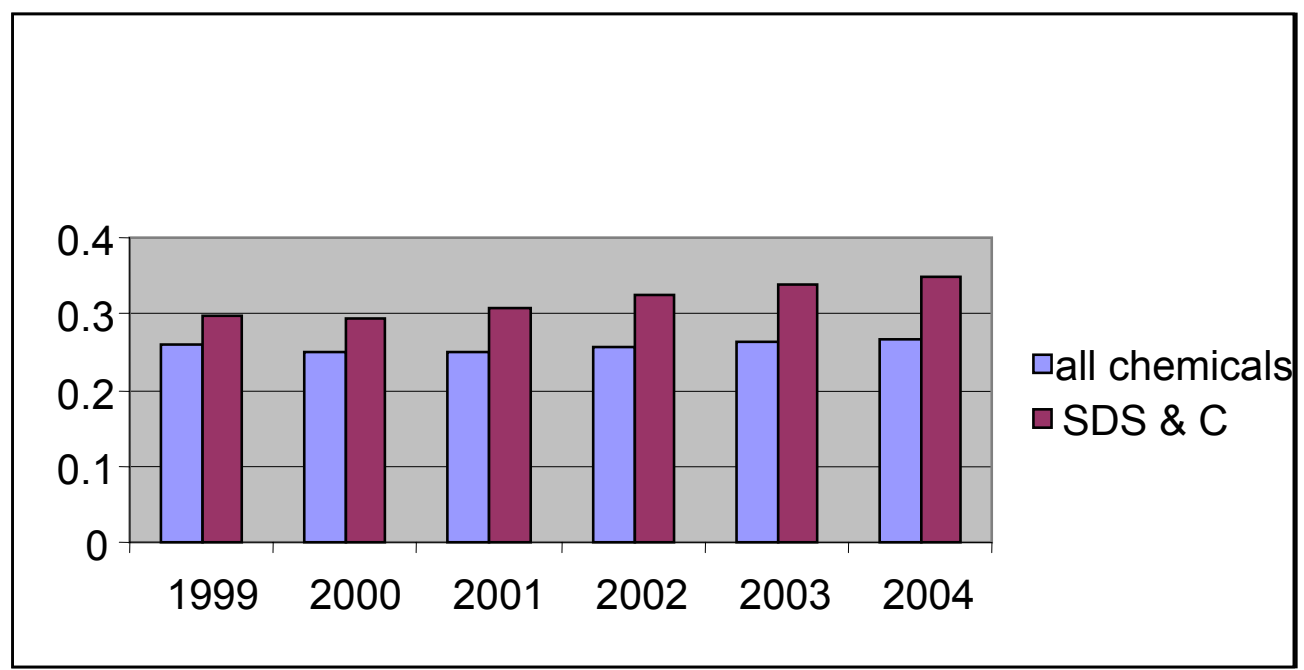

Source: INEGI (2005)

Rising gross margins have been possible because the industry has expanded production without a corresponding expansion in employment. While real value-added has expanded relatively rapidly for SDS and Cosmetics producers, employment has actually gone down substantially since 1999 (see Figures 3 and 4). The initial decline in employment was caused by the Tequila Crisis hit in 1994. But as output growth resumed in 1996 and thereafter, employment did not rebound. By 2004, real value-added had grown 50 percent and employment had shrunken more than 20 period, implying a 
cumulative improvement in real value-added per worker of nearly 90 percent!

Presumably this reflected the exit of relatively inefficient producers, the exploitation of scale economies, product and process innovation, and labor-shedding among those firms that continued to operate.

Figure 3

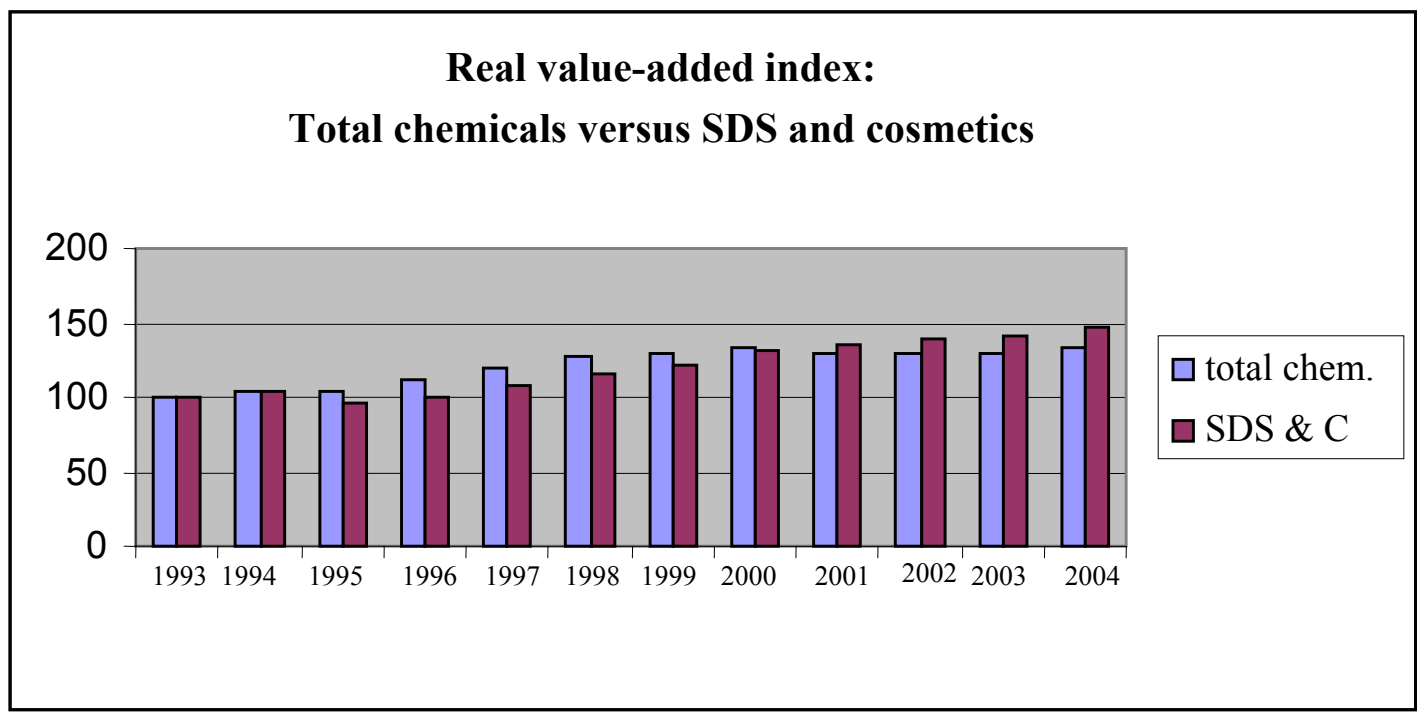

Figure 4

\section{Employment index: \\ Total chemicals versus SDS and cosmetics}

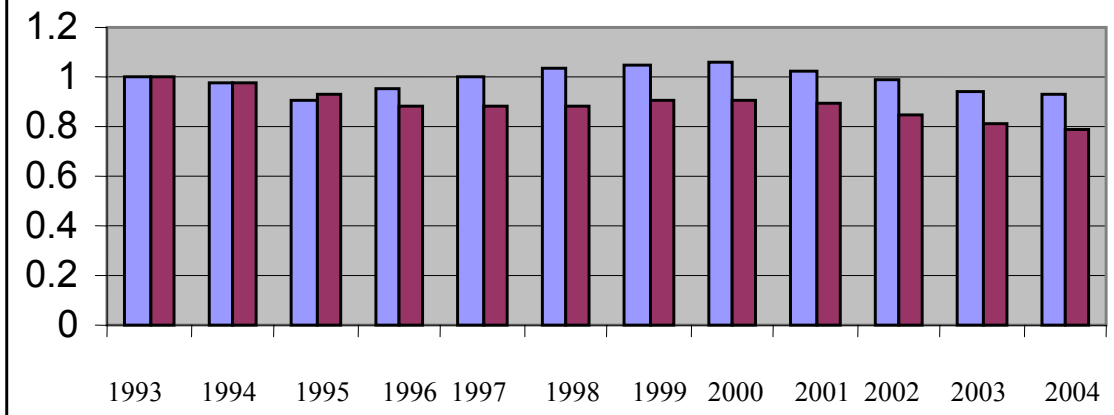




\section{Patterns of innovation and knowledge diffusion}

The heightened competitive pressure that Walmex brought to Mexico created incentives to cut waste and to innovate. We know from Figures 3 and 4 that labor productivity improved dramatically, and that some of this gain has come from labor shedding. But in addition, successful firms have increased their product appeal and improved their revenues per unit input cost through a variety of innovative activities. The interviews conducted for this study and recent papers on the SDS industry shed light on the sources of these process and product improvements. We summarize the basic messages below.

\section{Sources of innovation among multinationals}

Globally, the leading SDS producers are actively involved in product research and development. Modern detergent formulations, jealously guarded by the global industry leaders, are increasingly complex combinations of raw materials, formats, chemical additives and biotechnology. This complexity, coupled with competition and liberalized rules for international trade and investment, has pushed R\&D activity to be distributed globally, and integrated throughout the supply-chain.

Multinational detergent firms invest heavily in research. When Unilever launched its new concentrated powder in 1994, it had already invested $£ 100$ million in the technology, which contained a new bleaching system, new active ingredients, a new water softener system, used less energy and water to produce, and was more biodegradable (Ward, 1994). Henkel employed approximately 3,600 people worldwide in research and development activities in 1997. During the same year, the company devoted 
US\$ 247 million to R\&D, with a further US\$ 101 million being spent on technical services. A large portion of the research activities is concentrated at the headquarters in Düsseldorf. Product development and application engineering activities, on the other hand, are performed on a more decentralized basis. ${ }^{8}$

As the multinationals innovate, they often induce imitation among their competitors, and upstream adjustments among input suppliers. For example, when Proctor \& Gamble launched a detergent with built-in fabric softener in mid-2004, it not only sparked a race among competitors to create similar products, but it also spurred specialty chemical companies to develop the inputs that would be needed. Thus input suppliers sometimes serve as conduits for technology transfer to other firms, and increasingly, they are a source of research themselves (McCoy, 2001). ${ }^{9}$

Foreign affiliates operating in the Mexican markets benefit from the massive $R \& D$ investment undertaken by their parent companies, and draw on the innovations produced in the headquarters. They are the local market leaders in terms of introducing new and innovative products. However, not all innovations are accepted by Mexican customers. Consumer preferences for high-volume powder detergents limit the scope for launching premium-priced compact products.

\footnotetext{
${ }^{8}$ http://www.monografias.com/trabajos10/ugm/ugm2.shtml\#

${ }^{9}$ Globally, the nature of supplier research has been changing. R\&D partnerships are becoming more common, and several chemical companies are extending these alliances to include not only suppliers and customers, but other players in the chain, such as retailers and designers (Milmo, 2002). Rhodia, a leading specialty chemicals maker, dedicates 20 percent of its R\&D budget to research partnerships. Realizing the importance of speeding new products to market, suppliers are investing in high throughput equipment and trying to rise above the commodity-type pricing of inputs for existing products (Schmitt et al, 2002).
} 


\section{Sources of innovation among Mexican-owned firms}

While Mexican-owned detergent producers lack global economies of scale and thus the incentive to invest heavily in $R \& D$, many introduce incremental improvements to the regular powder format. They usually follow the lead of multinationals. Often they are prompted to do so by their customers, including Walmex. As mentioned above, product improvements help them avoid drastic price cuts demanded by Walmex. Such innovations usually involve introducing a new fragrance or changing the appearance of the product (by, for instance, adding blue inactive granules to the powder).

Input suppliers, usually foreign affiliates, are the primary channel through which Mexican-owned producers obtain access to innovations. According to the information obtained during the interviews, small Mexican producers meet with their input suppliers every six months to find out about the possibilities of upgrading their products. Suppliers provide the necessary inputs and often prepare a new formula for the product based on these inputs. To entice local producers, they can reformulate the product to substitute standard ingredients with their cheaper form in order to offset part of the increased input cost due to the innovative ingredients.

Mexican-owned producers often intentionally lag in introducing new products. For instance, from the Mexican firms' point of view, investing in liquid detergents to compete against large multinationals may not be a profitable strategy. Most prefer to wait until multinationals undertake the expensive task of educating consumers about the benefits of using liquid detergents and concentrated products. If a shift in broad perceptions of customers takes place, they can follow with similar products at less risk. For instance, one of the interviewed firms reported having the capacity to produce liquid 
detergents and expecting to have to use it in the future, but waiting until a perceptible shift in consumers' views has taken place and the demand for currently produced powder formulas has dwindled.

\section{Tailoring products to the local market}

Evolving consumer demand helps to induce continuous innovation, which is often specific to a particular market. Heightened sensibilities in the U.S. about the eutrophication of lakes and rivers prompted a reduction in phosphates, while general environmental concerns led to a shift in perceptions about volume. Detergent buyers in the U.S. now believe that compacts can clean as effectively as regular formulas, liquid formats dissolve better in the wash, and that fragrance and antimicrobial features are important. Antimicrobial characteristics have become especially important with rising energy bills and their ability to kill germs in cold water.

Mexican consumers have different preferences—-most notably for regular powdered detergent, with large amounts of sulfate filler to counter their relatively hard water. Because Mexican firms operate in a different regulatory environment and cater to these local preferences, they have not invested in the wholesale format changes that U.S. firms have made: from regular to compact powder, from compact powder to liquid, from regular liquid to compact liquid, or from compact liquid to tablet.

Many of the major new developments, including inputs, manufacturing processes and packaging, are designed for use with compact liquids that now represent the majority of sales in mature markets. This trend effectively precludes Mexican firms from importing several new detergent technologies unless they change their product format. In 
an industry long known for secrecy, leaders such as Proctor \& Gamble and Unilever are now even secretive about whom their suppliers are in order to prevent competitors from deducing formulations (Schmitt et al, 2002).

However, the interest in new additives among the large detergent makers and incentives to cut inventory costs have encouraged suppliers to develop inputs that are compatible across multiple formulations. Recent examples include surface modification for easy cleaning, surface adhesion for textile fabric care and time-controlled discharge of perfumes. Up to 90 percent of perfumes are destroyed during the wash and they account for as much as 30 percent of the input costs. Using latex, polymers and minerals such as silica and surfactants, researchers developed a controlled release that preserves 60 percent rather than 10 percent of perfumes (Milmo, 2002).

\section{Constraints to export response}

After 1994, Mexican SDS exports to the United States increased and Mexican producers captured a growing share of the U.S. import market. Figure 5 shows that Mexico's share in total US SDS imports rose from about 17 percent in 1994 to 27 percent in 2000 before falling somewhat. Also, while aggregate Mexican exports grew about 57 percent over the period 1994-1998, SDS grew somewhat more rapidly (81 percent), and continued to expand until 2001.

What forces drove the increasing success of Mexican SDS exporters in the U.S. market? Reductions in United States tariffs on Mexican exports of detergents to the U.S. may have played some role. However, these tariff rates were not high to begin with. 
Hence the real devaluation that accompanied the Tequila Crisis and the major productivity gains achieved the SDS industry were probably much more important.

Another important factor was the growing interest on the part of US supermarket chains to cater to the Latino population by providing "nostalgia brands" or "heritage brands." These are modestly-priced product that have well-established brand names in Latin American countries, and thus do not require costly promotional campaigns. Indeed, the firms interviewed indicated that Latinos constituted the core market for Mexican exports to the U.S. The most important firm to have tapped this market is Fabrica de Jabon La Corona, one of the largest laundry detergent producers in Mexico. In 2002, La Corona's sales in the U.S. of US\$15 million of powdered detergents and US\$10 million of liquid detergents amounted to a market share of one percent (Table 1). Gunnar Hallgrimsson, manager of international sales, said "It is very simple. There are a lot of Mexicans there. [We are] exporting to them a product they have been using all their life." For La Corona, South American markets have proved much less attractive than the United States, which received eighty percent of its exports in 2003. 


\section{Figure 5}

Mexico's SDS Exports to the US: Levels and Share of Total US SDS Imports

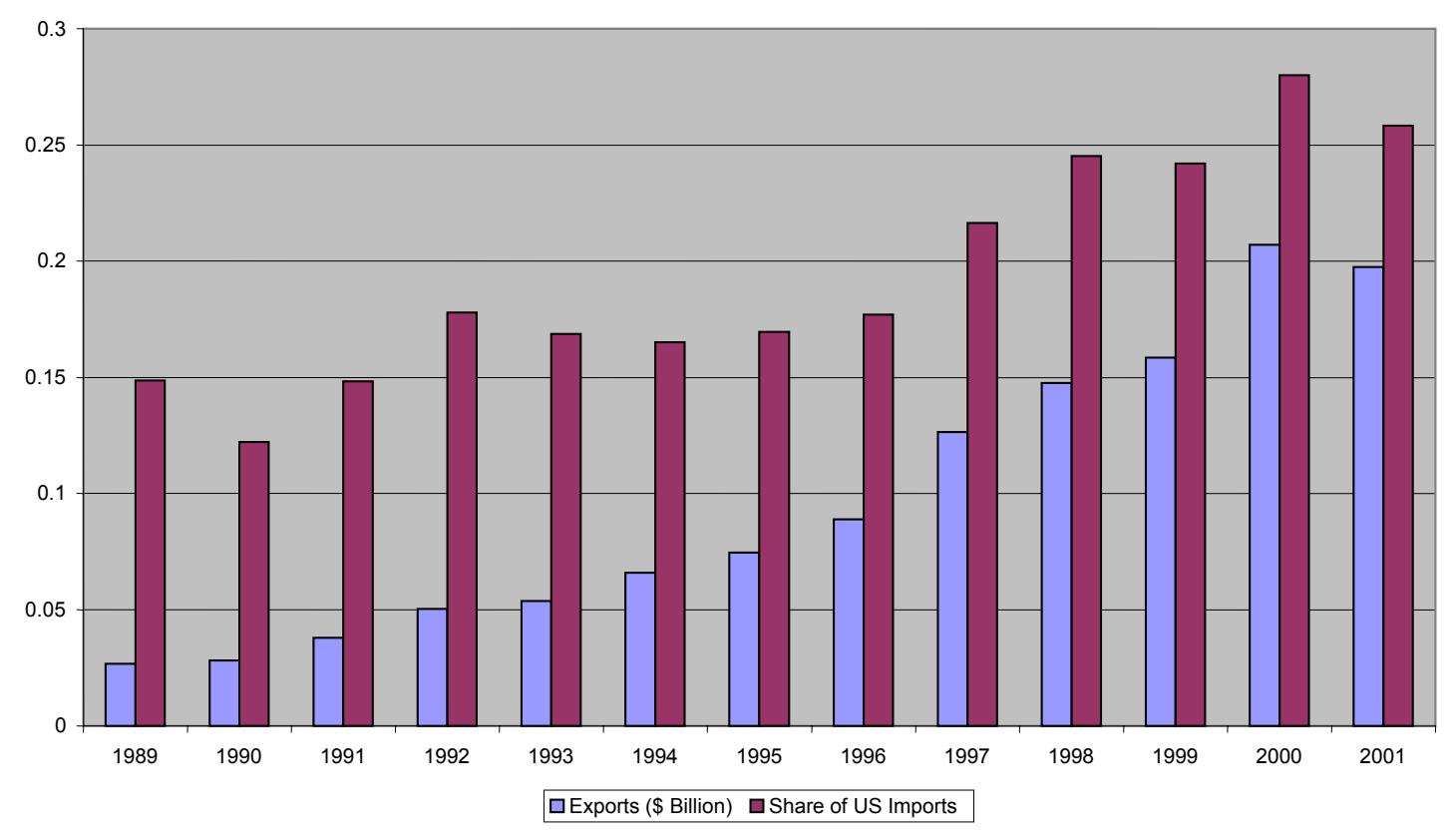

Table 1 - U.S. Sales of Laundry Detergents 2002 (\$ millions)

\begin{tabular}{lrrrr}
\hline & Powder & \multicolumn{1}{c}{ Liquid } & \multicolumn{1}{c}{ Total } & \multicolumn{1}{c}{ Share } \\
\hline Procter \& Gamble & 802.81 & 1307.15 & 2109.96 & $58 \%$ \\
Lever Brothers & 126.15 & 470.51 & 596.66 & $16 \%$ \\
Dial Corp. & 42.18 & 244.37 & 286.55 & $8 \%$ \\
Church \& Dwight & 77.42 & 116.28 & 193.70 & $5 \%$ \\
USA Detergents & 16.14 & 131.17 & 147.31 & $4 \%$ \\
Colgate-Palmolive & 18.90 & 111.65 & 130.55 & $4 \%$ \\
Private Label & 35.79 & 66.46 & 102.25 & $3 \%$ \\
Huish Detergents & 21.48 & 22.30 & 43.78 & $1 \%$ \\
Fabrica de Jabon La Corona & 14.97 & 10.03 & 25.00 & $1 \%$ \\
Redoc Brands & 4.62 & 9.99 & 14.61 & $0 \%$ \\
\hline Total Market & $\mathbf{1 1 6 5}$ & $\mathbf{2 5 0 2}$ & $\mathbf{3 6 6 7}$ & $\mathbf{1 0 0 \%}$ \\
\hline
\end{tabular}

Notes: includes sales from supermarkets, drug stores, and mass merchandisers, excl. Wal-Mart

Source: Information Resources Inc.

Multinationals operating in the SDS sector in Mexico are not actively engaged in exporting to the United States. Proctor \& Gamble does not export detergents to the 
United States, although some of its products are exported by wholesalers. Colgate no longer produces detergent in Mexico, having sold its Viva brand to Henkel in 2000, but it does export softener (Suavitel) to the United States. Henkel has been exporting Viva, its largest-selling brand, to the U.S. market for the past three years. Like the Mexican-owned producers, both Henkel and Colgate are concentrating on exporting familiar brands to the expanding diaspora of Latinos.

In sum, therefore, it appears that exporting to the United States is relatively unprofitable for Mexican firms, except in cases where their brands are already established in the Latino community. Similarly, the availability of relatively low-cost of Mexican labor does not appear sufficient to induce multinationals to shift production of non-Latino brands from the United States into Mexico and export them back to the United States.

\section{Transportation Costs}

Besides the costs of establishing brand recognition among non-Latinos, what keeps the return on exporting low? Perhaps the most obvious is transport costs.

Detergents have a low value to volume (weight) ratio, so transportation costs constitute a relatively large fraction of total revenues when they are shipped long distances. ${ }^{10}$ More compact detergents have higher value-density, use less packaging, and therefore offer significant cost-savings in distribution. For example, Unilever's All Small \& Mighty uses less than half the plastic packaging and saves an estimated 10 million gallon of water per

\footnotetext{
${ }^{10}$ The importance of transport costs to the industry is illustrated by the fact that liberalization of the trucking industry in the United States was a key factor driving consolidation of Proctor \& Gamble detergent production facilities in the country. Their number decreased from 14 in the late 1970s to only four in 2005. Though the transportation cost of more centralized production facilities is higher, the economies of scale in production offset the incremental shipping costs. There is also a cost savings achieved by lowering the transportation cost of inputs coming into 4 instead of 14 facilities.
} 
year to produce compared to its 100 -ounce size, substantially cutting manufacturing and other supply chain costs. The smaller size reduces diesel fuel consumption, translating into significant transportation savings (Walsh, 2006). But concentrated detergents have not proved popular among Mexican consumers, so the products Mexican firms offered in their local markets contain high levels of sulfate fillers and are particularly expensive to ship abroad. ${ }^{11}$

Importantly, transportation costs are increased by the regulatory environment. Trucking is the primary shipping mode between Mexico and the United States, representing about 85 percent of trade in terms of value (Haralambides and LondonoKent, 2004). ${ }^{12}$ Since NAFTA came into effect, cross-border trade by truck between the two countries has grown significantly (Figure 6). In Chapter 12 of the NAFTA, the three parties established parameters for cross-border trucking and in Annex I, they agreed to a timeline for phasing-out restrictions to cross-border provision of trucking services. In addition to allowing Mexican trucks access to the U.S. market, the agreement stipulated allowing U.S. interests to participate in the Mexican transportation sector.

However, the implementation of the this NAFTA provision was unilaterally suspended by the U.S. on the safety grounds. U.S. trucking associations and unions alleged that Mexican trucks posed a safety hazard as they were considerably older than the U.S. fleet and were not as well maintained. The Mexican side countered with the argument that safety should be a matter of technical inspection of individual vehicles and should not be addressed with a blanket prohibition. Moreover, a significant upgrading of

\footnotetext{
${ }^{11}$ Foreign producers attempted to introduce concentrated detergents in the Mexican market but the effort failed. The public did not appreciate the benefits of concentrated products and perceived a lower volume to be associated with a lower value of the product.

${ }^{12}$ Geographic distance in the U.S. costs about a dollar a truck-mile (Boyer 1997).
} 
the Mexican fleet had taken place since the introduction of NAFTA (Haralambides and Londono-Kent, 2004). Mexico challenged the blanket ban before a NAFTA arbitration panel which in 2001 found the U.S. to be in violation of NAFTA rules. A series of events in subsequent years paved the way for lifting the ban which, however, has not happened yet due to the lack of political will.

In addition to trucking restrictions, huge inefficiencies are present at the key U.S.Mexican border crossings. Crossing the Rio Grande river in the northbound direction with a loaded truck involves at least three pieces of equipment (trucks and trailers) and several drivers. ${ }^{13}$ The additional cost imposed at the border increases the cost of transport from Monterrey to Chicago by between 9 and 16 percent —see Table 2 (Haralambides and Londono-Kent, 2004).

\footnotetext{
${ }^{13}$ La Corona, the single major Mexican exporter, uses a third party logistics provider to enable less-thantruckload (LTL), multi-vendor consolidated load, or retail-driven consolidated shipments across the border to regional warehousing throughout the U.S.
} 


\section{Figure 6}

\section{Value of U.S. Land Imports from Mexico by Mode}

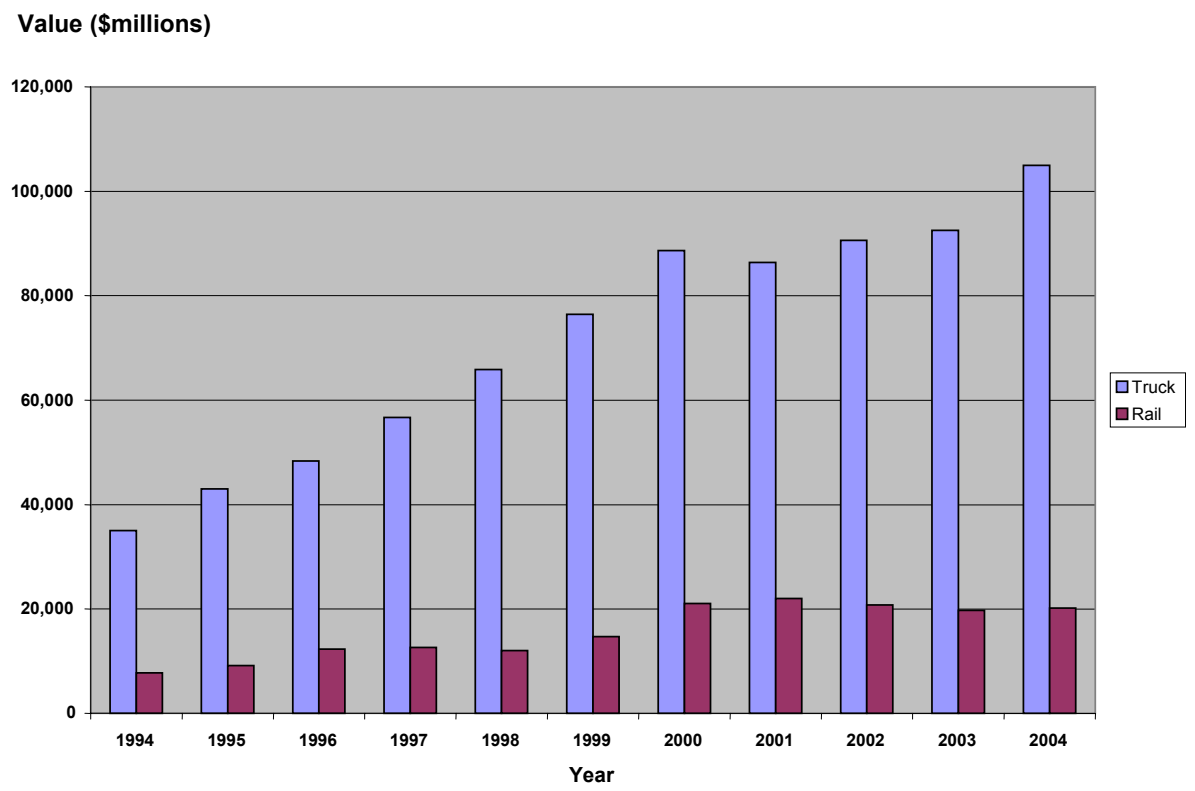

Source: http://www.bts.gov/publications/national_transportation_statistics/2005/html/table_01_54.html

Table 2 - Costs of Crossing U.S.-Mexican Border (Northbound)

\begin{tabular}{|c|c|c|c|c|}
\hline & \multicolumn{2}{|c|}{ Costs (US\$) } & \multicolumn{2}{|c|}{ Time (hours) } \\
\hline & Low & High & Low & High \\
\hline Mexican side & & & & \\
\hline Trucking Monterrey-Border & 188 & 210 & 2.5 & 3.0 \\
\hline Unloads and reloads as needed & 75 & 150 & 0.3 & 1.0 \\
\hline Drayage & 75 & 150 & & \\
\hline Mexican inspection & & & 0.0 & 2.0 \\
\hline Totals Mexico & 338 & 510 & 2.8 & 6.0 \\
\hline United States side & & & & \\
\hline Congestion, waiting time & & & 1.0 & 6.0 \\
\hline U.S. inspection & & & 0.0 & 4.0 \\
\hline Unloads and reloads as needed & & & 0.3 & 0.5 \\
\hline Trucking to Chicago & 1,338 & 1,343 & 30.0 & 51.0 \\
\hline Totals US & 1,338 & 1,343 & 31.3 & 61.5 \\
\hline Total U.S. \& Mexico & 1,676 & 1,853 & 34.0 & 67.5 \\
\hline
\end{tabular}

Source: Haralambides and Londono-Kent (2004, p.178). 


\section{U.S Environmental Regulations}

Another barrier to exports derives from environmental concerns in the U.S. In the 1960s a large public debate began over phosphate effluent from detergents and the resulting eutrophication of U.S. rivers and lakes. By the late 1960s, almost 10,000 lakes were reported to be suffering from excessive nutrient enrichment by human activities (ReVelle and ReVelle, 1988). As early as 1985 , jurisdictions which had enacted phosphate bans included New York, Michigan, Indiana, Vermont, Minnesota, Dade County, Florida, Akron, Ohio, and Chicago Illinois (Knud-Hansen, 1994). By 1996, more than 19 states and counties in 15 other states were limiting the phosphorous content of household laundry products to 0.5 percent. ${ }^{14}$ In 1999 , many regions of the U.S. had adopted phosphate limitations or bans, affecting about 40 percent of the U.S. population (Kostick 2004). The effects of these phosphate bans on consumption are apparent in figure 7 below.

Zeolites (hydrated aluminosilicates of the alkaline and alkaline-earth metals) are an environmentally friendly alternative to phosphates and are commonly used in liquid detergents as builders. ${ }^{15}$ The introduction of phosphate-reduced (1976) and later phosphate-free detergents (1983) marked the beginning of the era of builder systems containing zeolites. Many U.S. suppliers are also researching the building properties of soluble silicates. These can be used in both liquid detergents or in powders (after being spray-dried).

\footnotetext{
${ }^{14}$ Source: published summary of phosphate legislation from the Soap and Detergent Association. March 20 1996. http://www.ledizolv.com/LearnAbout/LeadDustCleaning/lszsixarg.asp

15 "Builders" serve to tie up mineral (hard water) ions, specifically magnesium and calcium, so surfactants can work better. They emulsify oil stains, reduce the re-deposition of dirt during washing and rinsing, provide alkalinity for cleaning and soften laundry water.
} 
Figure 7

\section{U.S. Soda Ash Balance}

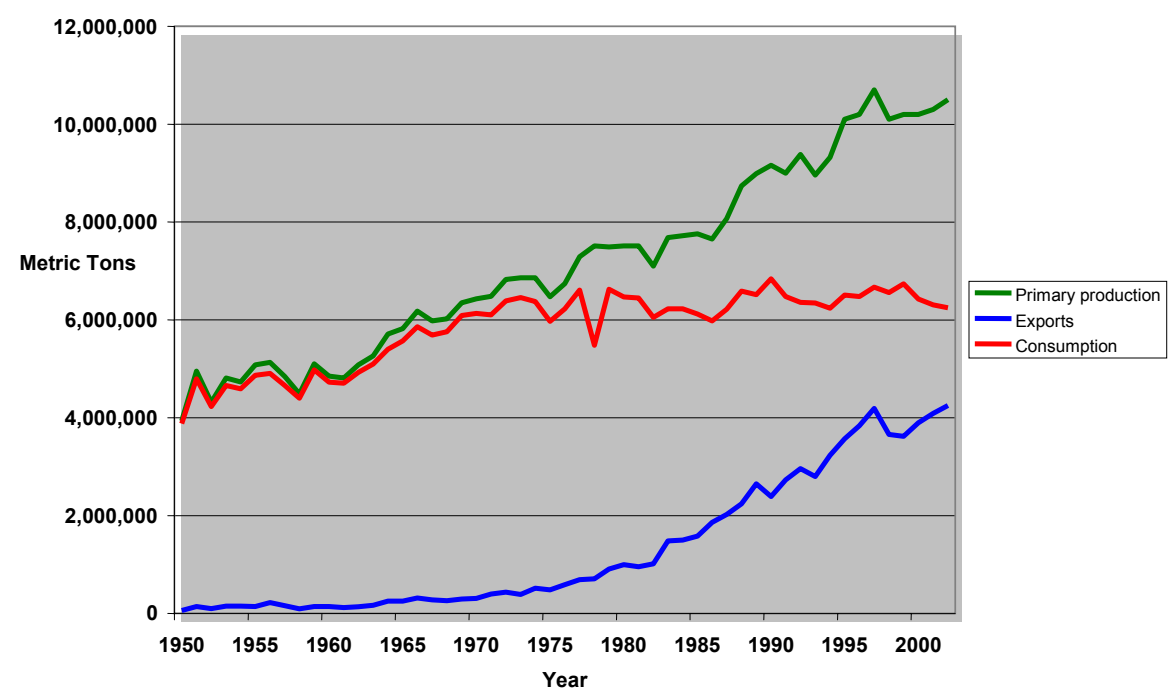

Source: USGS Historical Statistics for Mineral and Material Commodities in the United States 2003.

The water in Mexico is relatively hard, making phosphates a desirable ingredient to local consumers. According to the information obtained during firm interviews, most detergents produced in Mexico are phosphate-based and can only be legally exported to those U.S. states that have not enacted prohibitions. Switching production from phosphate-based to phosphate-free detergents and vice versa cannot be done without significant costs and producing both types of detergents at the same facility is not deemed to be commercially viable. 


\section{Intermediate input costs}

Finally, Mexican detergents are less competitive than they might be in the U.S. market because an important intermediate input—sodium hydroxide (chemical caustic soda) — is subject to Mexican antidumping duties (United States Trade Representative 2005). On July 2nd 2003, the Mexican National Oils, Fats, Soaps and Detergents Industry Association (CANAJAD) requested a NAFTA panel review under Chapter 19 of the countervailing duty (cuota compensatoria) imposed by the Secretary of the Economy on sodium hydroxide originating in the U.S. According to CANAJAD, this countervailing duty has effectively given monopoly power to two local producers which supply most of the product to the Mexican market. Presumably due to the lack of political will, no ruling has taken place yet.

\section{Conclusions}

The first message of this study is that traditional approaches to analyzing trade agreements may miss important implications. In the case of the SDS sector, Mexico’s GATT- and NAFTA-related commercial policy reforms mattered little in terms of their direct effect on SDS trade and innovation. However, they helped to induce the entry of Wal-Mart into Mexico, which in turn led to fundamental changes in the structure of the SDS sector and in the retail sector in general. More precisely, the entry of Walmex led to:

- the dissemination of the latest retail techniques to other retail chains and increased competition in the retail sector;

- waste reductions in bringing goods to market; 
- scale economy exploitation by those Mexican-owned and foreign producers that sold to Walmex;

- greater incentives for small-scale local producers to adopt innovations;

- movement toward marginal cost pricing, even among the major brands; and

- exit of some of the less efficient SDS producers.

The second message of the paper is that the full benefits of improved market access may not be realized in the presence of non-tariff barriers to trade. In the case of the Mexican SDS industry, the competitiveness of local producers is severely hindered by inputs costs being inflated due to the anti-dumping measures that protect Mexican producers of caustic soda and by the limited competition in the trucking sector causing delays and inflating costs.

Neither of these barriers to trade is insurmountable, and both could be removed with the stroke of pen. Whether they would lead to dramatic growth in Mexican exports is difficult to predict, but the nature of the North American SDS market suggests that this is a possibility. More precisely, Mexican producers who wish to export to non-Latinos in the United States face two types of start-up costs: they must establish brand recognition and trust in this market, and they must re-tool their production facilities to produce phosphate-free liquid concentrates instead of bulky, phosphate-intensive powders. It is possible that for a number of firms, the pay-offs in terms of future export profits are just shy of these start-up costs, in which case a modest increase in operating profits per unit export could trigger a significant export boom. On the other hand, it is also quite possible that exporting to the non-Latino in the U.S. is far from profitable for Mexican firms, and 
that reductions in transport costs and input prices would have little effect on trade flows. $^{16}$

The third lesson is that innovation and adoption of innovations is very sensitive to incentives. By giving local producers an opportunity to tap into a larger market, and by insisting on steady price reductions for products that remain unimproved, Wal-Mart created a powerful incentive for SDS producers to improve product quality and/or productive efficiency. Although it is beyond the scope of this paper to isolate the effects of this incentive on productivity in the SDS sector, value-added per worker clearly improved rapidly as Walmex gained market share.

Finally, industry-wide growth in value-added per worker reflected a combination of labor shedding and innovation, and much of the innovation that took place among SDS producers was traceable - directly or indirectly — to multinationals. For the multinational SDS subsidiaries, innovation was largely accomplished through the research efforts of their headquarters abroad. For the Mexican-owned SDS firms, innovation originated largely with their intermediate suppliers, who regularly brought them new compounds and suggestions for new products or processes. Many of these suppliers were themselves foreign-owned, and some of the inputs they brought to Mexican-owned firms were developed in response to the needs of the major multinational producers.

\footnotetext{
${ }^{16}$ Das et al. (2006) quantify start up costs and export operating profits for several Colombian manufacturing industries. They find that among knitted fabric producers, many were near the threshold of probitable exports. Thus when the Colombian peso depreciated in late 1980s, large numbers began to penetrate foreign markets. In contrast, leather product suppliers were much more heterogeneous in terms of their payoffs from exporting, so only a few responded to the devaluation by initiating foreign sales
} 


\section{References}

Basker, Emek (2005) "Selling a Cheaper Mousetrap: Wal-Mart's Effect on Retail Prices," Journal of Urban Economics 58, pp. 203-229.

Business Planning Solutions (2005). The Economic Impact of Wal-Mart.

Chavez, Manuel. (2002)."The Transformation of Mexican Retailing with NAFTA," Development Policy Review 20(4), pp 503-13.

Cuevas, Alfredo, Miguel Messmacher, and Alejandro Werner (2005). "Foreign Direct Investment in Mexico since the Approval of NAFTA", World Bank Economic Review Advance Access, December 6, 2005.

Das, Sanghamitra, Mark Roberts and James Tybout (2006). "Market Entry Costs, Producer Heterogeneity, and Export Dynamics," Pennsylvania State University, Department of Economics. (Earlier version appeared as NBER working paper 8629.)

Fishman, Charles (2003). “The Wal-Mart You Don't Know," Fast Company (Decmber) 77. Downloaded February 15, 2006 from http://pf.fastcompany.com/magazine/77/walmart.html.

Haralambides, H.E. and Londoño-Kent, M.P. (2004) "Supply Chain Bottlenecks: Border Crossing Inefficiencies between Mexico and the United States," International Journal of Transport Economics, 31 (2): 171-183.

INEGI (2005). La Industria Química en México. Aguas Calientes: INEGI. Downloaded April 8, 2006 from www.inegi.gob.mx

Kostick, Dennis S. (2004). Soda Ash. U.S. Geological Survey Minerals Yearbook. 2004. p.71.

Knud-Hansen, Chris (1994). "Historical Perspective of the Phosphate Detergent Conflict." Natural Resources and Environmental Policy Seminar, University of Colorado. February.

McCoy, Michael (2001). “Soaps \& Detergents: Product Report,” CENEAR, 79(3), pp.19-24.

Milmo, Sean (2002). "Rhodia Adopts Innovative Alliances to Foster Product Development." Chemical Market Reporter, 262(15).

ReVelle, P. and C. ReVelle (1988). The Environment: Issues and Choices for Society. 3rd ed. Jones and Bartlett Publishers. Boston. 
Schmitt, Bill, Morrison, Scott, Walsh, Kerri (2002). "Margin Woes Agitate Surfactants Makers," Chemical Week.164(3).

Soap and Detergent Association (1996) Published summary of phosphate legislation. March 201996.

http://www.ledizolv.com/LearnAbout/LeadDustCleaning/lszsixarg.asp

Tegel, Simon (2003). "Every Day Higher Sales: Mal-Mart Wunderkind Walmex shows them how it's done in a down economy: The Giant 24," Latin Trade (August). Downloaded February 15, 2006 from http://www.findarticles.com/p/articles/mi_m0BEK/is_8 11/ai_106860473

United States Trade Representative (2005). National Trade Estimate Report.

Walsh, Kerri (2006). "Brand Extensions Clean Up.” Chemical Week.168(4).

Ward, Mike (1994). "Unilever Unveils New Generation Compact Detergent Powder." Chemical Week.154(17). 


\section{Appendix:}

\section{Major Policy Reforms and Macro Shocks: 1965-2005}

During the last four decades, Mexico's policies towards international trade and foreign direct investment have been characterized by a general trend towards liberalization. At the same time, this has been punctuated by several policy reversals in times of crisis that typically lasted only a few years. We offer a chronology of the major episodes below.

Import Substitution until the 1960s:

Until the mid-1960s, Mexico's economic policy was typical of the import substitution paradigm that pervaded Latin America. This meant generally highly protectionist trade and foreign direct investment (FDI) policies. During the late 1960s and early 1970s, there were some initiatives of liberalization, both in terms of trade as well as certain foreign direct investments. For example, the first maquiladora program was authorized in the year 1965 (and subsequently liberalized in 1972). However, the changes made tended to be selective, carried by an apparent belief that highly directive government policy can guarantee good outcomes. Specifically, the general Law on Foreign Investment, passed in 1973, remained highly restrictive with respect to foreign ownership of firms in Mexico.

\section{4 oil price shock:}

The first oil price shock in the year 1974 led to a current account deficit in Mexico. The Mexican exchange rate stayed initially at the fixed rate of 0.0125 Pesos per 
\$ US, but a recession contributed to the decision to let the Peso devalue by the year 1977. The oil price shock also triggered a pattern of policy reversal that would be typical for Mexico over the last four decades, as the limited trade liberalization measures that were put in place since 1970 were now reversed.

\section{Second oil price shock and 1982 debt crisis:}

In the late 1970s, Mexico started tapping into newly discovered oil reserves on its territory. Thus the second oil price shock of 1979 initially benefited Mexico. With the windfall of increased oil revenues, the country dramatically extended its international borrowing. However, at least ex-post most of these projects turned out to have a low long-run rate of return. Mexico's international debts were mounting, and in the year 1982 the Mexican government declared default on its international debt obligations.

\section{GATT membership in 1985:}

During the mid-1980s, the Mexican exchange rate was in free-fall versus the dollar, with an average rate of depreciation versus the dollar of around $65 \%$ per year between 1981 and 1988. A number of measures were taken to stabilize the Mexican economy, including structural adjustment programs agreed upon with the major international lending organizations. The key policy change was that Mexico joined the General Agreement on Tariffs and Trade (GATT) in the year 1985. GATT membership served as the anchor for the initial push of domestic and international trade reforms during 1985-1988 that substantially liberalized the Mexican economy. From 1985 to 1990, Mexico's average import tariff rate fell from 24 percent to 13 percent, while the 
import quota coverage ratio fell from 92 percent in 1985 to 20 percent in 1990. Along the same lines, the new Law on Foreign Investment of 1989 represented a major relaxation relative to the 1973 law, and a number of state-owned enterprises were privatized during the years 1989-92. Import licensing continued to decline in importance during the early $1990 \mathrm{~s}$.

\section{NAFTA treaty in 1994:}

In June of 1990, the United States and Mexico indicated their intention to extend the Canada-US trade agreement to include Mexico, thus forming the North American Free Trade Agreement (NAFTA). After several years of negotiations, NAFTA was finally ratified by the US Congress in November 1993 and implemented on January 1, 1994. The far-reaching changes sought by NAFTA were

- the gradual elimination of tariffs

- the abolishment of most non-tariff barriers

- the opening-up of government purchases

- the liberalization of foreign investment

- the elimination of barriers for service companies

- $\quad$ the promotion of competition within countries

- $\quad$ greater protection of intellectual property rights

- the creation of dispute settlement mechanisms

Among the important principles laid down in the NAFTA treaty are national treatment and most-favored nation treatment (NAFTA Article 102). National treatment for goods 
means that once goods have been imported into any NAFTA member country, they will not be subject to discrimination (including by sub-federal governments). Most-favored nation treatment implies that the signatories of NAFTA have to extend trading benefits to each other equal to those accorded to any--that is, the most favored--non-NAFTA country.

Overall, two features of the NAFTA agreement stand out as particularly important. First, Chapter 11 investment gives private investors the means to seek arbitration against NAFTA governments. This means that private companies need not rely on their own government to take up their case. Second, and more generally, by signing the NAFTA treatment Mexico has further committed itself to the trade and FDI liberalization policies it began in the mid-1980s. This "tying-one's-own-hand" aspect of NAFTA may be its single most important aspect, since it lowers the risk of policy reversals, and is associated with less policy uncertainty more generally.

\section{4 'Tequila' Crisis and aftermath:}

In December of 1994, lax banking laws and a record fiscal deficit combined to trigger the so-called 'Tequila Crisis.' As the exchange rate regime collapsed, the Peso depreciated 123 percent vis a vis the dollar and GDP contracted by about 6 percent, leaving Mexico in its worst recession since the 1930s. However, in contrast to earlier crises, there was no major policy reversal in terms of Mexico's trade and investment policies - retrenchment essentially amounted to a moderate increase in import tariffs. This was partly due to the NAFTA commitments, and partly because Mexico became a member of the OECD in 1994 and a member of the new World Trade Organization in 
1995. Mexico's relatively steady policy course was also facilitated by a $\$ 50$ billion aid package from the United States.

In 1996, the Mexican government further liberalized foreign direct investment by opening areas for FDI that before were reserved for the Mexican government, such as railways. In 1999, following the Asian financial crisis, some import tariffs were again slightly raised, but compared to earlier protectionist responses to crises, the general scale of these policies was fairly minor. 